\title{
Transformation Of Information Technology Capacity As A Marketing Media Of The "Lontar Sewu" Tourism Village, Hendrosari Village, Gresik Regency
}

\author{
Author \\ Sukaris Sukaris, Budiyono Prestyadi, Al kusani \\ Correspondence \\ Management Study Program, Faculty of Economics and Business \\ Universitas Muhammadiyah Gresik \\ Sukaris21@umg.ac.id
}

\begin{abstract}
Problems that occur in partner tourism villages are that village tourism is still managed and marketed improperly so that it is less marketable that relies on conventional marketing with marketing knowledge resources that are still not optimal, the main problems are marketing management knowledge, marketing personnel, and mastery of marketing support technology. The purpose of this activity is to transform the capacity of information technology as a marketing media for tourism villages specifically, first; by strengthening institutional capacity and human resources (training and mentoring), secondly; strengthen digital marketing of tourist villages. Methods of implementing activities through Focus Group Discussion (FGD) with POKDARWIS; the second phase is strengthening the institutional capacity of BUMDES and POKDARWIS. The result of the activity is that the BUMDES and POKDARWIS managers have been able to transform the 3-P strategy which includes segmenting targeting and positioning. Managers must be able to combine and internalize the 3-P strategy into digital marketing strategies. Suggestions for managers are first; managers must update the capacity on mastering the latest marketing technology so that they can keep up with the changing tastes of visitors' tastes. Service must be the package of activities so that the strategy to improve service quality becomes an inseparable part of all marketing efforts both conventional and digital.
\end{abstract}

Keywords: Transformation, Digital Marketing, Tourism Village, Marketing Strategy.

Received: 15 Januari 2020. Accepted: 20 Januari 2020.

\section{Introduction}

Hendrosari Village has a majority of farmers as farmers. The northern boundary of the Hendrosari Village area is bordered by Pandu Village, Cerme District. The southern region is bordered by Boboh Village, Menganti District. The West boundary with Cerme Village, Cerme Subdistrict and the eastern region is bordered by Kepatihan Village, Menganti District. Hendrosari village has around 2,681 inhabitants, one of the most remote villages in the Menganti sub-district. As for the detailed population, as of December 31, 2019, are residents by sex: Male: 1,345 people, Female: 1,336 people. Total Amount: 2,681 Life. The number of households and households; 1 . The number of Family Heads:
769 households and 2. Number of Households:

716 Houses. Residents based on livelihood / occupation are as follows: Not yet/not working: 470 people, Managing household: 355 people, Students / Students: 602 people, Retired: 3 people, Civil Servants: 43 people, Members of TNI / Polri: 6 people, Entrepreneurs: 64 people, Farmers / Farmers: 225 people, Breeders: 3 people, Fisheries: 0 people, Industry: 0 people, Private Employees: 976 people, Freelance Daily Workers: 3 people, and Amount: 2,681 People.

Population-based on Education; Not/not yet in school: 470 people, not yet graduated elementary school/equivalent 120 people, graduated elementary school or 457 people, graduated junior high school 
equivalent to 345 people, high school graduate equivalent: 1,115 people, Diploma I/II/III degree 45 people, bachelor: 160 people, Strata I / Diploma IV: 9 people, strata II 11 people, strata III 3 people so that the number of 2,681 people in the village of Hendrosari was also covered with $\pm 3,600$ trees. Based on data the number of Lontar trees divided, as follows:

a. Legen Producing Lontar Trees: 2,126 Trees (792 productive)

b. Lontar Tree Producing Siwalan Fruit: 1,474 Trees (515 productive)

c. Number of Lontar Trees: 3,600 Trees

The number of sap and Siwalan fruit produced every day on average every day as follows:

a. Nira1190 Liters

b. Siwalan Fruit $80 \mathrm{~kg}$ Peel

The coordinates of Hendrosari Village are at -7

○ 14'22,867 "S 112 34'52,976" E which has a distance of about $4 \mathrm{~km}$ from the center of Menganti District. Road access is good and paving up to the tourist location of "Lontar Sewu".

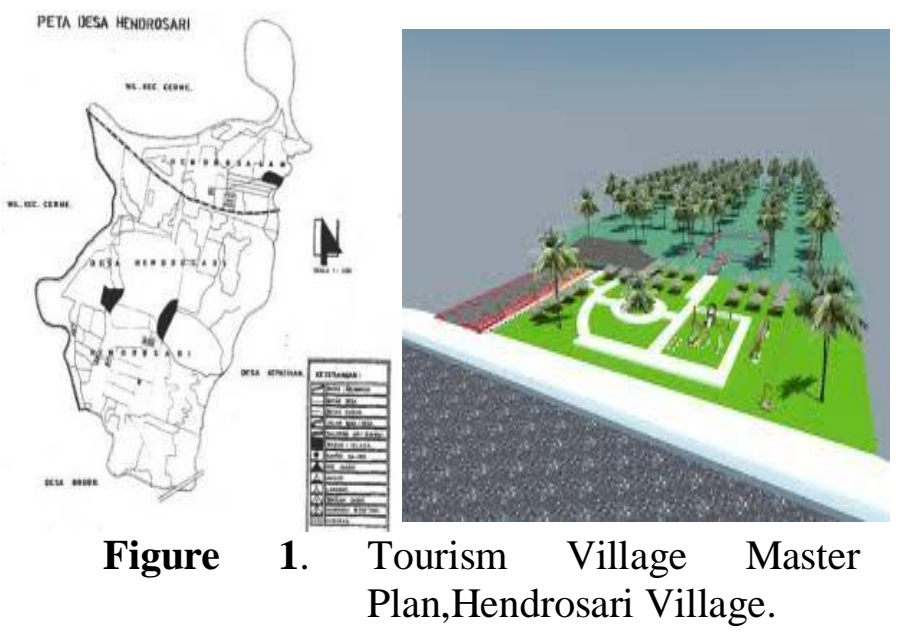

Other tourism development that is still not optimal as part of village tourism packages such as fishing ponds, and the potential for further development is edu agricultural tourism such as planting and harvesting agricultural products.
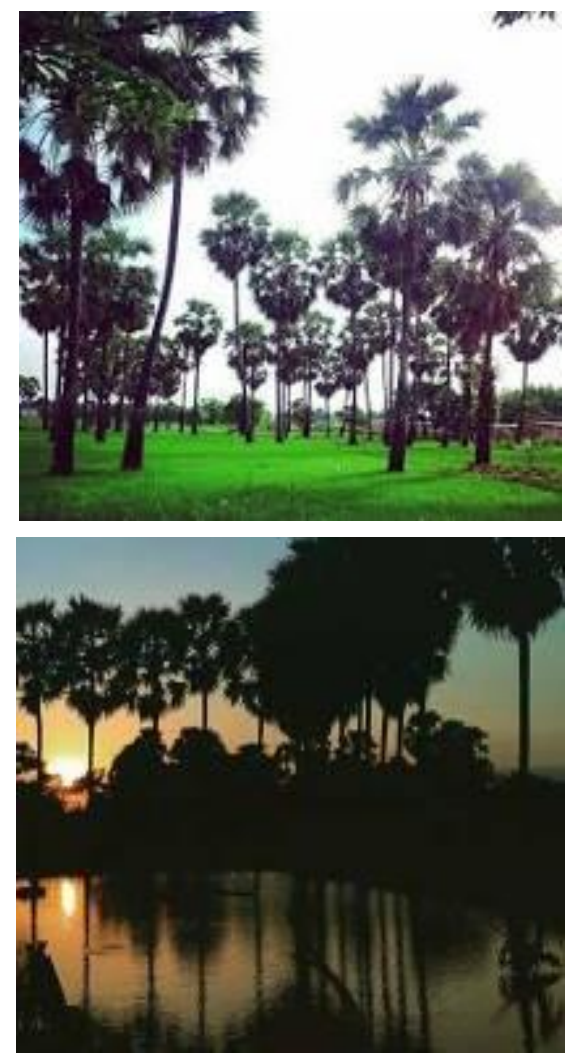

Figure 2. Situation of fishing ponds and Lontar trees

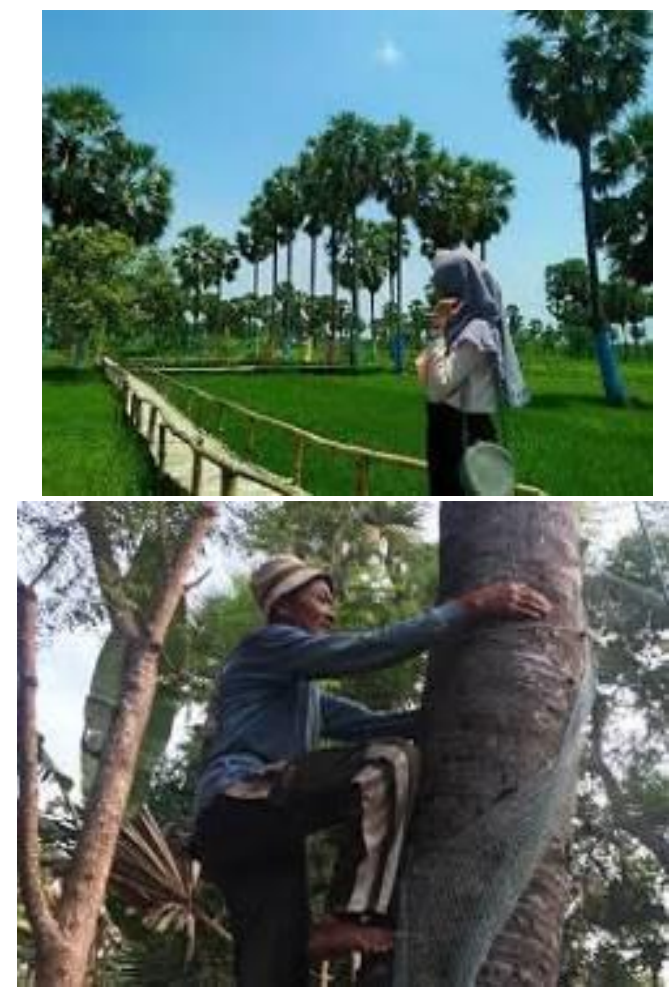

Figure 3. Agricultural Tourism Situation 
Tourism potentials, if managed and developed effectively, will provide a multiplayer economic effect for the community as Biggs, (2008) that development of tourism which is oriented towards local potential is important for increasing income and prosperity. Likewise Fandeli, (2001) Community empowerment through community awareness and approaches is needed so that they can use and have access to control in developing tourist villages. Tourism activities by utilizing local resources have been developed based on sustainable economic goals, supporting environmental preservation efforts, and improving the welfare of local communities.

In this endeavor, the production process is the production process of tourism services by selling travel experiences, namely village tourism products which besides offering a water park arena the village also offers activities in daily community life offered to be enjoyed by visitors who visit Hendrosari village. Visitors can enjoy the life activities of the local village community, the majority of which are farming, such as traditionally cultivating agricultural land (nandur (planting rice), and manyi (harvesting rice), harvesting siwalan from lontar trees, making various preparations made from legen, as well as the daily life of other local people, visitors can also do other educational activities such as tree climbing, culinary tours and so on. Currently village tourism is managed in the management of Village-Owned Enterprises, labor comes from villagers, and other income is by renting booths in the area of the water park. Village tourism business management is still managed simply and many do not use technology. The existence of a tourism village will foster other productive businesses that will increase the economy of the community. Preparation and strengthening of management needs to be done in addition to building awareness of the importance of increasing the family's economy through entrepreneurship in the village by utilizing opportunities for a tourism village.

The lack of success in village economic activities can occur because community groups have not been comprehensively involved in every process of regional development, development and utilization of available resources in the region. Tourism village is one of the potentials that can be used as an alternative source of income for the community and will lead to the potential development of productive economic activities of citizens, but in its development there are several problems including; first, human resources, where a) people are not yet ready to join the POKDARWIS and BUMDES in preparing themselves after the tourism village has been established. Second is technology mastery, which is the ability in the form of expertise related to digitalization (digital marketing), this makes village tourism not yet known to many people electronically and the fulfillment of IG media, Facebook YouTube and marketing with Android-based mobile.

\section{Method}

Problems Partner problems that become priority are tourism villages that have been completed and become productive assets of the village have not been maximally marketed to become marketable products with strong branding and ready to be bought, visited by the public (consumers), this is caused by several problems including: first, human resources, where a) people are not yet ready to join POKDARWIS and BUMDES in preparing themselves after the tourism village has been established, Second is technological mastery, namely the ability in the form of expertise related to digitalization (digital marketing), so with this dedication how to expand marketing access to tourism villages so that they are increasingly recognized by the community, have a positive image, many visitors and provide a multiplayer effect on the productive 
efforts of citizens as supporting village tourism such as souvenirs, culinary and others. The initial stage of the proposer is the first stage; Focus Group Discussion (FGD) with citizens and stakeholders, especially managers of BUMDES and POKDARWIS; the second phase is strengthening the institutional capacity of BUMDES and POKDARWIS villages, the third is creative digital marketing training and the creation of social media networks and the ability to provide services to visitors.

\section{Results and Discussion}

Based on the proposed activity plan, the results of community service activities are described as follows:

1. Identification of priority issues with BUMDES and POKDARWIS management partners, based on discussions (participatory) and meetings conducted and field observations, resulted in several problems that need to get attention is the development and marketing of lontar sewu tourism villages, these problems are related to resources ( resources) destination resources as being able to transform the mastery of current digital technology into effective promotional media, (Hudson \& Shephard, 1998) are:

a. Human Resources

1) The readiness of the BUMDES and POKDARWIS managers in preparing themselves to market the tourist village of "lontar sewu tourism".

2) Supporting skills in the form of expertise related to marketing, and networking

b. Technology

Marketing capabilities that use technology in the form of expertise related to digitalization (digital marketing), social media networking.

c. Environment

1) Citizens' readiness in reading business opportunities as a double impact for businesses prepared by villages and communities

2) Villages already have strong barriers related to siwalan producing villages "siwalan villages and villages that have unique

d. Material / physical resources

1) Lontar tourist village tourism sites in general have a strong capital as a tourist village

2) Edu tourist sites still need polishing, even though some places are naturally ready.

3) Already have a site related to business startups connected with other tourism in the village such as fishing ponds.

e. Partnership

Efforts should be made with other partners in preparing tourism villages that offer several tour packages including, fishing ponds, tree climbing, outbound, agriculture, and open discussion rooms.

f. Funds

Effectiveness of Funding sourced from the allocation of village funds

2. At the implementation stage which includes; choose some problems that might be done to contribute to the preparation in developing a tourist village. Based on this identification, an optional program was chosen which then cooperates into an activity that can be carried out, namely the transformation of the capacity of information technology as a marketing media for "Lontar Sewu" tourism villages.

Activities undertaken include; observation community awareness of the existence of a tourist village that is currently being developed, strengthening soft skills in marketing, especially strategies in transforming resource capacities that focus on digital marketing and finally is improving services for visitors or tourists. 
At the observation stage the following information and data are obtained:

a. That the community members are aware of a village program that will develop the village into a better tourism village.

b. The community realizes that the village has unique natural tourism potentials such as; lontar tree plantations that are not owned by other villages.

c. The community has the awareness that they have all the necessary assets such as other supporting resources such as fishing ponds, reservoirs, rice fields that can be a source of excellence.

d. The tourism manager has also very understood the potential of integrated tourism that will be developed

e. The community has strong social capital including cooperation, mutual trust and being able to network with other citizens.

f. The village realizes that they have unique resources that are not owned by other villages.

In the presentation of information technology capacity transformation material as a marketing medium for tourism villages, the results of activities can be described as follows:

a. In the initial stage, a joint awareness is made that the community and managers (BUMDES and POKDARWIS) are aware of and know what products will be sold. So it is necessary to discuss the needs and desires of visitors for the desired destination product.

b. b. Efforts to market digitally need to be realized that the use of technology focuses on technical capabilities but needs to be supported by the ability of the concept of marketing strategy concepts. So that the 3-P strategy must still get capacity strengthening for managers, namely segmenting, targeting and positioning. Organizations that want to succeed in marketing activities must have the awareness that it is not possible to serve all the buyers available in the market. Prospective buyers also have demands in their purchases, so the right strategy is needed in serving these buyers (Sukaris, 2018).

c. In the elaboration phase of needs and desires it is known that the visitors later are those who want a tourist village or a pleasant tourist destination based on local uniqueness.

d. In the segmenting strategy, it can be seen that the groups that can be selected and served are the school children 's education community in early and elementary school, as well as the adolescent age group and the family segment and geographically the region is the segment of visitors coming from the city.

e. In the targeting strategy, the target is the education community.

f. At the product positioning stage, this positioning even though it requires data to build what people will think of this tourism village tourism brand. As Sukaris stated $(2018 ; 38)$ that segmenting, targeting can only be achieved when the organization has a positioning favorable in the minds of the target market in certain product or service categories, as the life of positioning as a marketing strategy, the purpose of which is to occupy a different position, relative towards a competing brand in the mind of the consumer and this is about perception competition.

g. In digital marketing, an important part of attention is to transform expertise in the use of social media for marketing purposes by basing on existing data, which are the most widely used media in finding tourist destinations that you want to visit namely, facebook, instagram and whatsApp user groups . 
The results showed that browsing activity on Instagram has a positive influence on flow conditions, online trust, and purchase intentions. Then online trust in accounts on Instagram has a positive influence on the flow conditions. Likewise, the variable flow conditions and online trust also have an influence on the intention to purchase the latest items on Instagram (Nata, JH and Sukaris, 2018).

h. Service, as an intangible product, service is an important part to package a tourist village that increasingly touches the hearts of visitors. Service delivery is not only tangible but also intangible. For an organization to succeed in the long run, it must create services that meet the needs and desires of its users (Sukaris \& Pristyadi, 2017).

Based on community service activities that have been carried out through the Focus Group Discussion (FGD) method, workshops, and participatory, then;

a. Strengthening capacity in developing 3-P strategies, namely segmenting, targeting and positioning

b. Periodic evaluations are needed based on visit data relating to visitor segments so that at certain periods the targeting and positioning of destination products can be improved.

c. Creating a unique and expected tourist village tagline in the long run becomes the top mind in the minds of visitors.

d. Strengthening branding through massive movements with the villagers of Hendrosari through social media, for example: loading DP (display fiction on whatsApp, or IG)

e. Traditional marketing efforts need to be complementary to digital marketing efforts.

f. Strengthening the community's social capital, especially community involvement in the management of tourism villages, thus the community's love for village businesses becomes even greater. Strengthening the social capital of this community will make the community more responsible for an activity, willing to participate to make the program successful, interact with other citizens, the spirit of cooperation with other citizens, increase mutual trust with others, can equate ideas with citizens another. (Suwandi et al., (2019)

g. Strengthen the quality of service capacity for managers, workers to create visitor satisfaction and loyalty

\section{Conclusions}

Can the achievement of community service implementation activities have been carried out by Transforming the Capacity of Information Technology as a Marketing Media for Tourism Villages, specifically the transformation that can be done is;

1. BUMDES and POKDARWIS managers have been able to implement a 3-P strategy that includes segmenting targeting and positioning

2. The ideas of product positioning have been understandable especially the alternative positioning proposed for the "Lontar Sewu" village tour

3. Managers must be able to combine and internalize the 3-P strategy into digital marketing strategies.

4. Managers must make a capacity update on the mastery of the latest marketing technology so they can keep up with the changing desires of visitors who often change their tastes.

5. Service must be the package of activities so that the strategy to improve service quality becomes an inseparable part of all marketing efforts both conventional and digital. 


\section{References}

Biggs, S. (2008). Learning from the positive to reduce rural poverty and increase social justice: Institutional innovations in agricultural and natural resources research and development. Experimental Agriculture, 44(1), 3760.

Fandeli, C. (2001). Perencanaan Kepariwisataan Alam. Yogyakarta: Fakultas Kehutanan UGM.

Nata, J. H.dan Sukaris (2018). Mobile Display Advertising" Pengaruh Aktifitas Browsing, Flow Dan Kepercayaan Online Terhadap Niat Pembelian Barang-Barang Terbaru Di Instagram (Studi Pada Follower Akun Instagram Kategori Produk Fashion, Gadget, dan Kuliner di Surabaya). In Seminar Nasional Dan Call For Paper Inovasi Bisnis Dan Manajemen (Inobis) 2018. Inobis.

Sukaris S, B. P. (2017). The Effect Of E-Service Qualityon The Satisfaction Through Perceived Value On Web-Based Academic Services. Journal Homepage:-www. journalijar. com.

Sukaris, S, (2018). A War In Mind : Segmenting, Targeting Dan Positioning Untuk Memasarkan Perguruan Tinggi Swasta. UMG Press, https://onesearch.id/Record/IOS5571. 1002

Sukaris, S. 2018. Kajian Empiris Dalam Pemosisian Produk. Jurnal Riset Entrepreneurship, 1(2), 1-12

Suwandi, S., Sukaris, S., \& Faris, A. (2019). Model CSR dalam Penguatan Modal Sosial dan Peran Kelembagaan Masyarakat. Akuntabilitas, 12(1), 105118. 